\title{
PRAKTIK ILLEGAL TRANSHIPMENT DI LAUT LEPAS BERDASARKAN HUKUM LAUT INTERNASIONAL
}

\author{
Elisabeth Septin Puspoayu*, Cindy Yunita Sari**, dan Virania Cahya Ramadhani****
}

Fakultas Ilmu Sosial dan Fakultas Hukum, Universitas Negeri Surabaya

Jln. Ketintang, Surabaya, JawaTimur, 60231

\begin{abstract}
Illegal transhipment practice is a serious problem because it is included in the theft mode of fish, which is by transferring the cargo of fish that occurs in the middle of the high seas from one ship to foreign ships without reporting the catch. It categorized as one form of the criteria for Transnational Organized Crime/TOC, includes crimes committed in one country, but involves organized criminal groups from more than one country. This paper will construct how the dispute resolution process must be carried out if it consists of UN procedures, UNCLOS 1982 by "International Tribunals for the Law of the Sea (ITLOS)" and the Association of Southeast Asian Nations (ASEAN) Regional. The type of research used is normative juridical.
\end{abstract}

Keywords: transhipment, high sea, dispute settlemenae.

\section{Intisari}

Praktik illegal transhipment merupakan suatu permasalahan yang serius karena termasuk dalam modus pencurian ikan, yaitu melalui pemindahan muatan ikan yang terjadi di tengah laut lepas dari satu kapal ke kapal asing tanpa melaporkan hasil tangkapannya tersebut. Dikategorikan sebagai salah satu bentuk kriteria Transnational Organized Crime/TOC, meliputi kejahatan yang dilakukan di satu negara, akan tetapi melibatkan kelompok kriminal terorganisasi yang berasal lebih dari satu negara. Tulisan ini akan mengonstruksikan bagaimana proses penyelesaian sengketa yang harus dilakukan bilamana terdiri atas prosedur PBB, UNCLOS 1982 oleh "International Tribunal for the Law of the Sea (ITLOS)", dan Regional Association of Southeast Asian Nations (ASEAN). Jenis penelitian yang digunakan ialah yuridis normatif.N.

Kata Kunci: transhipment, laut lepas, penyelesaian sengketa.

\section{Pokok Muatan}

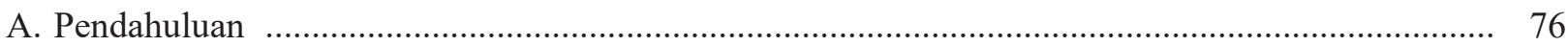

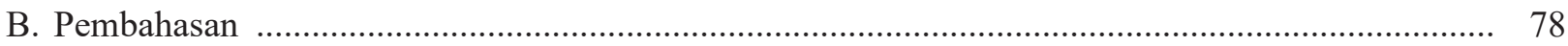

1. Kriteria Praktik Illegal Transhipment di Laut Lepas Sebagai Transnational Organized Crime . 78

2. Bentuk Penyelesaian Sengketa Praktik Illegal Transhipment di Laut Lepas Berdasarkan

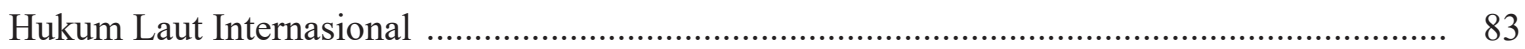

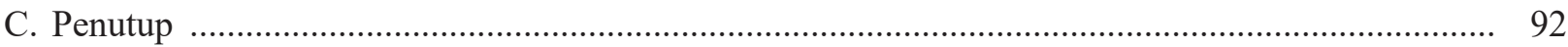

Alamat korespondensi: aiuelisabeth@gmail.com.

Alamat korespondensi: cindyyunita286@gmail.com.

*** Alamat korespondensi: viraniacahya@gmail.com. 


\section{A. Pendahuluan}

Pada umumnya, perikanan mempunyai peranan penting dan strategis terhadap pembangunan perekonomian nasional, terutama mengenai perluasan kesempatan kerja, pemerataan pendapatan, peningkatan taraf hidup bangsa, pembudidayaan ikan, sampai pada pihak pelaku usaha di bidang perikanan. Hal ini dilakukan dengan tetap memelihara lingkungan, kelestarian, dan ketersediaan sumber daya ikan. Penangkapan ikan dan alat yang dipergunakan berkembang sangat cepat untuk memperoleh ikan dalam waktu relatif singkat dan jumlah yang cukup besar. Contoh perairan Negara Indonesia yang mempunyai potensi kekayaan sumber daya laut yang begitu besar, memberikan sejumlah peluang dan tantangan. Perairan Indonesia menyajikan berbagai sumber daya guna kesejahteraan atau kemakmuran bagi bangsa Indonesia baik memenuhi kebutuhan rakyatnya maupun keperluan ekspor suatu negara. Sementara itu, Indonesia menghadapi suatu tantangan untuk menjaganya dari potensi ancaman. Salah satu tantangan terbesar bagi Indonesia adalah menjaga teritorial perairannya dari aktivitas penangkapan ikan secara illegal. Maraknya aktivitas ini mengancam kelangsungan hidup industri perikanan Indonesia.

Indonesia merupakan negara maritim terbesar yang memiliki luas daratan sebesar $1.910 .931,32 \mathrm{~km}^{2}$ dan luas lautnya yang mencapai $3.544 .743,9 \mathrm{~km}^{2}$ yang terdiri dari laut territorial sebesar 284.210,90 km2, Zona Ekonomi Eksklusif (ZEE) sebesar 2.981.211,00 km², dan laut $12 \mathrm{mil}$ atau sebesar 279.322,00 $\mathrm{km}^{2}$. Kemudian dengan dirilisnya peta laut Indonesia yang dikeluarkan pada tanggal 14 Juli 2017, dimana setelah ratifikasi beberapa perjanjian internasional yang menjadikan wilayah perairan laut Indonesia bertambah seluas 100 mil laut sehingga Indonesia adalah satusatunya di Asia Tenggara yang memiliki ZEE lebih dari 200 mil laut. ${ }^{1}$ Indonesia dengan lautnya yang begitu luas, ekosistem yang berada di bawahnya pun sangat kaya. Bahkan berbagai macam makhluk laut langka banyak terdapat di Indonesia. Selain itu, bisa menarik perhatian sejumlah kapal nelayan asing guna melj 1 akukan kegiatan tindak pidana penangkapan ikan secara illegal. Contohnya perompakan atau pembajakan, yang menyebabkan pencemaran air laut hingga terjadinya perubahan iklim ekstrim, dan klaim atas wilayah laut oleh berbagai negara yang didasarkan atas kedaulatan negara menurut hukum internasional. Salah satu faktor terjadinya illegal fishing adalah kebutuhan ikan dunia (demand) meningkat, namun disisi lain pasokan ikan dunia menurun, maka menyebabkan kelebihan permintaan (overdemand), selain itu negara juga mengalami sejumlah kerugian yang mencapai angka triliunan yang patut dimintakan pertanggungjawaban.

Terkait pokok permasalahan modus illegal fishing oleh asing terus berkembang. Adanya sanksi berupa penenggelaman dan pembakaran kapal yang diberikan oleh Menteri Kelautan dan Perikanan, Ibu Dr. Susi Pudjiastuti, terkait pelanggaran kapal asing terhadap penangkapan ikan di wilayah perairan Negara Indonesia, tidak membuat pelaku pencurian tersebut merasakan jera. Melainkan, semakin memicu upaya strategis atau cara terbaru yang telah dirancang, sehingga dapat menyebabkan besarnya kerugian ekonomi di Indonesia, yaitu praktik illegal transhipment. Martin Tsamenyi, ${ }^{2}$ menyebutkan bahwa transhipment merupakan salah satu modus pencurian ikan. Modus transhipment artinya pemindahan muatan ikan yang terjadi di tengah lautan lepas dari satu kapal ke kapal asing. Modusnya, kapal tersebut menjual ikannya di laut lepas tanpa melaporkan hasil tangkapannya, baru pada tangkapan terakhir atau saat periode perizinan hampir berakhir. Mereka biasanya melaporkan kepada pejabat yang berwenang di Indonesia. 
Saat di kapal pun, pencatatan jumlah ikan yang ditangkap tidak dihitung kembali secara cermat. Jadi melalui transhipment, kapal penangkap tidak perlu lagi kembali ke pangkalan setelah muatan ikan penuh. Kapal penangkap hanya menunggu kapal pengumpul (collecting ship) untuk mengambil ikan hasil tangkapan, dan pada saat itu pula kapal pengumpul menyuplai bahan bakar, bahan makanan, serta kebutuhan lainnya kepada kapal penangkap ikan tersebut. Jelas bahwa transhipment dapat mengefektifkan operasi penangkapan dan mengefisiensikan biaya operasional penangkap. ${ }^{3}$

Sebagai contoh kasus illegal transhipment di Benoa, Bali. Di mana, jaringan illegal fishing di tengah laut melakukan kegiatan transhipment (alih muatan) kepada kapal induk dari Taiwan. Dari kasus transhipment illegal fishing di Benoa, Bali, Menteri Kelautan dan Perikanan, Ibu Dr. Susi Pudjiastuti, mengungkapkan kerugian negara bisa mencapai miliaran rupiah. Selain itu, beliau mengatakan, "Apabila hasil ikan yang didapat dengan menggunakan kapal longline (tipe kapal penangkap ikan yang panjang) sekali ke laut 30 ton dan 1 ton seharga USD 5. Selama 8 (delapan) bulan, oknum-oknum tersebut dapat melaut 8 (delapan) hingga 10 (sepuluh) kali". ${ }^{4}$ Adapun ciri - ciri modus illegal transhipment yang dilakukan, ialah:

1) Modus pertama pinjamizin. Modusnya, yakni dengan menggunakan dokumen izin penangkapan ikan milik kapal lain,

2) Modus kedua ganti baju. Modusnya, yakni dengan menggunakan kapal eks asing yang diubah seolah - olah menjadi kapal buatan dalam negeri. Umumnya, kapal berbadan fiber dilapisi kayu. Dengan modus ini, pemilik kapal dapat mendaftarkan kapalnya pada izin kapal perikanan Provinsi Bali dan izin perikanan dari pemerintah pusat, dan

3) Terakhir modus ketiga, yakni pulang tanpa deregistrasi (tidak lapor ulang). Modus ini dilakukan oleh pemilik kapal eks asing dengan cara keluar dari wilayah Indonesia tanpa melalui proses deregistrasi. Alasan yang umum disampaikan, yakni kapal akan dijual ke luar negeri dan registrasi dilakukan setelah kapal tiba di negara tujuan. Modus ini, antara lain dilakukan karena pemilik kapal tidak dapat melaksanakan syarat deregistrasi untuk menunjukkan validitas dan legalitas dokumen kapal.

Berdasarkan uraian di atas, terdapat sebuah permasalahan yang diuraikan pada jurnal ini, yaitu bagaimana kegiatan illegal transhipment dalam persoalan wilayah perairan Negara Indonesia apabila ditinjau dari PBB, UNCLOS 1982 oleh "international tribunal for the law of the sea (ITLOS)" dan Regional ASEAN.

Jurnal ini termasuk dalam sebuah karya tulis yang asli.

Berdasarkan uraian latar belakang diatas, penulis mengangkat beberapa permasalahan yang akan dibahas untuk lebih lanjut dengan judul jurnal "Praktik Illegal Transhipment di Laut Lepas Berdasarkan Hukum Laut Internasional”. Adapun permasalahan tersebut, sebagai berikut: Pertama, Bagaimana kriteria praktik illegal transhipment di laut lepas dapat dikategorikan sebagai Transnational Organized Crime?; dan Kedua, Bagaimana penyelesaian sengketa illegal transhipment di wilayah laut lepas menurut hukum internasional? 


\section{B. Pembahasan}

1. Kriteria Praktik Illegal Transhipment

di Laut Lepas Sebagai Transnational Organized Crime

Suatu kegiatan penangkapan ikan dinyatakan illegal apabila dilakukan didalam wilayah kedaulatan suatu negara pantai namun dilakukan dengan cara yang melanggar peraturan hukum nasional dan internasional, seperti menangkap ikan di wilayah kedaulatan Indonesia namun tidak memiliki izin dan bukan pada lokasi yang telah ditentukan atau tanpa izin. Oleh sebab itu, kegiatan penangkapan ikan diluar wilayah ZEE seperti di laut territorial, laut pedalaman, dan zona tambahan bukanlah pelanggaran selama tidak melanggar peraturan nasional yang mengatur mengenai penangkapan ikan, dalam hal peraturan yang dimiliki Indonesia ialah Keputusan Menteri Kelautan dan Perikanan Republik Indonesia Nomor Kep.50/Men/2012 tentang Rencana Aksi Nasional Pencegahan dan Penanggulangan Illegal, Unreported, And Unregulated Fishing Tahun 20122016. Hak kebebasan melakukan pemanfaatan dan pengelolaan sumber daya hayati, salah satunya ialah kesempatan untuk melakukan kegiatan penangkapan ikan oleh negara yang berbendera. ${ }^{5}$

Pihak yang secara utama wajib memperhatikan ketentuan mengenai Jumlah Tangkapan yang Diperbolehkan (JTB) ialah kapal penangkap ikan asing. ${ }^{6} \mathrm{Jadi}$, hak suatu negara guna menangkap ikan di perairan negara lain dibatasi oleh ketentuan tersebut. Berbicara mengenai laut lepas merupakan keseluruhan bagian dari laut yang tidak termasuk dalam zona ekonomi eksklusif (ZEE), laut territorial, perairan pedalaman suatu negara, atau dalam negara kepulauan. Implikasi dari definisi tersebut membuat laut lepas dicadangkan untuk maksud damai, baik dari aspek navigasi maupun sumber daya alam yang terkandung di dalamnya, harus dapat dinikmati oleh seluruh umat manusia dan tidak boleh dimonopoli oleh satu atau beberapa negara saja. Jawahir Thontowi dan Prannoto Iskandar dalam bukunya menyatakan bahwa pada prinsip "freedom of the sea" di laut lepas tidak berlaku kedaulatan, hak berdaulat, atau yurisdiksi suatu negara, laut lepas merupakan "res communis", yaitu laut yang terbuka dan bebas bagi semua negara. ${ }^{7}$ Dengan demikian, dapat terjadi tindak pidana penangkapan ikan secara illegal oleh kapal nelayan asing, contohnya pembajakan kapal, perdagangan gelap, dan penyiaran yang tidak sah.

Selain itu, sejumlah ketentuan di laut lepas sebagaimana dikemukakan oleh J.G Starke, sebagai berikut: $^{8}$

1) Bahwa laut lepas tidak dapat diletakkan di bawah kedaulatan suatu negara tertentu. Terdapat kebebasan mutlak menangkap ikan di laut lepas ini bagi kapal semua bangsa, baik niaga maupun kapal perang;

2) Bahwa pada umumnya, suatu negara tidak boleh menjalankan yurisdiksi atas kapal yang tidak memakai bendera negaranya;

3) Bahwanegarahanya dapatmenjalankan yurisdiksi atas kapal tertentu yang mengibarkan benderanya;

4) Bahwa setiap negara dan warganya berhak menggunakan laut lepas, misalnya untuk memasang kawat atau kabel serta pipa di dasar laut (freedom of immersion); dan

5) Bahwa terdapat kebebasan mutlak penerbangan di atas laut lepas bagi semua pesawat.

Negara-negara dalam hal ini dapat bekerjasama dalam mengamankan wilayah laut, akan tetapi hal tersebut hanya dilakukan pada teritori wilayah negara pantai, dan tidak dapat mengintervensi kedaulatan negara lain, termasuk pula di laut milik yurisdiksi negara lain. Pada Laut

\footnotetext{
Ketentuan ini terdapat dalam Pasal 62 ayat (2) dan (3) United Nation Convention on the Law of the Sea (UNCLOS) tahun 1982.

Jumlah Tangkapan yang Diperbolehkan (JTB) adalah perhitungan secara sistematis jumlah ikan yang diperbolehkan untuk ditangkap, setelah memperhatikan tingkat regenerasi sumber daya ikan dan daya dukung lingkungan (DDL). JTB ditetapkan oleh pemerintah otoritas pemegang kedaulatan dan hak berdaulat atas sumber daya ikan yang berada di wilayah perairannya.

Jawahir Thontowi, et.al., 2006, Hukum Internasional Kontemporer, PT. Refika Aditama,Bandung, hlm. 189.

J. G. Starke, 1988, An Introduction to International law, Butterworths, London, hlm. 57.
} 
Lepas, kepemilikan laut dimiliki oleh Internasional, bahkan setiap negara memiliki hak untuk kebebasan menangkap ikan. ${ }^{9}$

Berdasarkan prinsip kebebasan, semua negara baik negara berpantai atau tidak, dapat menggunakan laut lepas dengan syarat mematuhi ketentuan yang ditetapkan oleh konvensi atau ketentuan hukum internasional lainnya. Menurut Pasal 87 Konvensi Hukum Laut 1982, meliputi :

1) Freedom of navigation;

2) Freedom of overflight;

4) Freedom to lay submarine cables and pipelines, subject to Part VI;

5) Freedom to construct artificial islands and other installations permitted under international law, subject to Part VI;

6) Freedom of fishing, subject to the conditions laid down in section 2; and

7) Freedom of scientific research, subject to Parts VI and XIII.

Kebebasan tersebut harus dilaksanakan oleh setiap negara dengan memperhatikan hak negara lain dalam melakukan hak kebebasan di laut lepas berdasarkan syarat yang telah ditentukan dalam Konvensi Hukum Laut 1982 dan ketentuan lain dalam Hukum Internasional. Dari keenam prinsip kebebasan di laut lepas tersebut, salah satunya ialah prinsip kebebasan melakukan penangkapan ikan. Kebebasan bukan memberikan kekuasaan bagi pihak manapun, namun kebebasan diberikan dengan konsep perlindungan, hingga kegiatan yang dilakukan di wilayah laut lepas tidak sampai merusak perairan dan sumber daya alam hayatinya. Dampak yang paling rentan dari segala tindakan di laut lepas, yaitu berkurangnya stok sumber daya hayati. Akan tetapi, pelaksanaan kebebasan ini harus dibarengi dengan diindahkannya ketentuan mengenai langkah konservasi sumber daya hayati di laut lepas dan Organisasi pengelolaan perikanan internasional yang telah dimiliki oleh FAO, dengan berbagai instrument yang mengisyaratkan pembentukan instrument regional dan nasional untuk menguatkan perlindungan sumber daya maritim.

Organisasi selain RFMOs telah ada dan banyak dimiliki oleh negara kawasan praktik Kejahatan illegal transhipment dapat dikatakan tidak jauh berbeda terhadap illegal fishing lintas batas negara dimulai dari kejahatan perizinan, kejahatan pengangkutan ikan, sampai pada kejahatan penangkapan penggunaan teknologi semacam LED ikan atau spektrum cahaya yang dihasilkan dari lampu LED, sehingga dapat menarik plankton yang mengundang ikan kecil untuk datang, kemudian ikan berukuran besar datang untuk memakan kumpulan ikan kecil tersebut, maka terjadilah sebuah rantai makanan dan kumpulan ikan di sekitar bagan atau rumpon yang kemudian masuk ke dalam jaringjaring nelayan. Namun, proses pemindahan ikan (transhipment) di laut lepas merupakan cara terbaru penangkapan ikan illegal bagi kapal nelayan asing. Menurut Nikijuluw memberikan penjelasan definisi tentang illegal fishing, yaitu: ${ }^{10}$

1) Kejahatan Perikanan Destruktif, dapat diterjemahkan menjadi praktik penangkapan ikan dengan menggunakan bahan kimia, bahan biologis, bahan peledak, alat atau cara yang dapat merugikan atau membahayakan kelestarian sumber daya ikan dan lingkungannya.

3) Kejahatan Penggunaan Teknologi, penyimpangan teknologi perikanan, yaitu kejahatan yang dilakukan jika seseorang memiliki, menguasai, membawa atau menggunakan alat penangkapan ikan atau alat bantu penangkapan ikan yang tidak sesuai dengan ukuran dan standar yang ditetapkan, tidak sesuai dengan persyaratan dan dilarang penggunaannya. Semacam LED atau spektrum cahaya yang dihasilkan dari lampu LED, sehingga dapat menarik plankton yang mengundang ikan kecil untuk datang, kemudian

Tjondro Tirtamulia, Zona-Zona Laut UNCLOS, (Surabaya: Brilian Internasional, 2011), hlm. 72.

Victor P. H. Nikijuluw, 2008, Dimensi Sosial Ekonomi Perikanan Illegal: Blue Water Crime, PT Pustaka Cidesindo, Jakarta. 
ikan berukuran besar datang untuk memakan kumpulan ikan kecil tersebut, maka terjadilah sebuah rantai makanan dan kumpulan ikan di sekitar bagan atau rumpon yang kemudian masuk ke dalam jaring-jaring nelayan.

6) Kejahatan Perizinan, kejahatan perizinan merupakan kejahatan dimana si pelaku praktik penangkapan ikan ilegal tidak memiliki izin penangkapan di suatu wilayah penangkapan dari otoritas yang bersangkutan dan segala sesuatuhal dan kegiatan yang berhubungan dengan praktik penangkapan ikan dilakukan dengan tidak ada izin atau tidak sesuai dengan izin dari otoritas setempat,

7) Kejahatan Pengangkutan Ikan, kejahatan pengangkutan ikan merupakan kegiatan pengangkutan ikan yang dilakukan secara ilegal dan tidak dilaporkan secara langsung dari perairan suatu negara ke luar negeri. Praktik ini akan mengurangi kemampuan suatu negara untuk mencatat jumlah sebetulnya produksi ikan, dimana data produksi riil ini sangat penting karena dapat digunakan sebagai basis estimasi potensi dan tingkat pemanfaatan sumber daya perikanan di suatu negara. Selain itu, praktik ini juga akan menyebabkan industri pengolahan produk perikanan di daratan akan mengalami kekurangan suplai bahan baku, yang dapat berakibat pada banyaknya pabrik yang menganggur, tutup dan gulung tikar. Dampak jangka panjangnya adalah banyak kesempatan kerja yang hilang, dan

8) Kejahatan Perusakan Lingkungan, termasuk didalamnya pencemaran, perusakan sumber daya ikan dan lingkungan, pembudidayaan ikan dengan menggunakan rekayasan genetika yang membawa dampak negatif, serta penggunaan obat-obatan dalam pembudidayaan ikan yang juga berdampak negatif. Kejahatan ini tidak berkaitan langsung dengan praktik penangkapan ikan ilegal. Pada tingkat skala usaha perikanan komersial yang umumnya menggunakan kapal dan alat tangkap ikan ukuran besar, kegiatan kerusakan lingkungan barangkali tidak dijumpai. Namun pada skala usaha kecil tradisional, yang menyangkut dan melibatkan nelayan kecil (subsistence fishers) yang lebih menerapkan strategi kelangsungan hidup jangka pendek (short - life subsistence strategy), maka praktik penangkapan ikan ilegal dapat berdampak pada lingkungan. Beberapa contoh praktik penangkapan ikan ilegal skala kecil adalah penggunaan potas, sianida (cyanide fishing), bom, bahan peledak (dynamite fishing) dan aliran listrik (electrical fishing) yang dapat merusak lingkungan.

Indikasi menunjukkan bahwa tingkat tangkapan (catch rate/hoog rate) baik di Samudra Hindia maupun Samudra Pasifik terlihat lebih tinggi di laut lepas dibandingkan di ZEE Indonesia. Dalam kerangka implementasi ketentuan Konvensi Hukum Laut 1982 yang terkait, pada 4 Desember 1995 PBB mengadopsi Agreement for the Implementation of the Provisions of the UNCLOS of 10 December 1982 relating to the Conservation and Management of Straddling Fish Stocks and Highly Migratory Fish Stocks (United Nations Implementing Agreement) UNIA) 1995.

Indonesia sebagai negara yang secara aktif memperjuangkan pengembangan hukum internasional dalam UNCLOS 1982 serta berbagai ketentuan pelaksanaannya secara yuridis memiliki konsekuensi untuk meratifikasi UNIA 1995 sebagai salah satu pelaksanaan UNCLOS 1982 yang telah diratifikasi Indonesia melalui UndangUndang Nomor 17 Tahun 1985 tentang Pengesahan Konvensi Perserikatan Bangsa-Bangsa tentang Hukum Laut Tahun 1982. Berdasarkan ketentuan UNIA 1995, konservasi dan pengelolaan jenis-jenis ikan yang bermigrasi jauh dimandatkan untuk diatur lebih lanjut dalam organisasi perikanan regional (Regional Fisheries Management Organization/ RFMOs). ${ }^{11}$ Pada saat ini telah berdiri beberapa RFMOs yang berada di sekitar Indonesia, antara 
lain Komisi Tuna Samudera Hindia India Ocean and Tuna Commision (IOTC), Komisi Perikanan Untuk Pasifik Barat dan Tengah Western and Central Pasific Fisheries Commision (WCPFC), dan Konvensi tentang Konservasi Tuna Sirip Biru Convention on The Conservation of Southern Bluefin Tuna (CCSBT). ${ }^{12}$

Sejumlah inisiatif telah diambil Indonesia, diantaranya dengan mengadopsi sejumlah ketentuan internasional yang diharapkan dapat memperbaiki situasi pengelolaan dan pelestarian perikanan nasional. Saat ini, Indonesia telah menjadi pihak pada dua RFMO yang ada, yaitu Indian Ocean Tuna Commission (IOTC) dan Commission for the Conservation of Southern Blufin Tuna (CCSBT), serta menjadi cooperating non - members pada Commission for the Conservation and Management of Highly Migratory Fish Stocks in the Western and Central Pacific Ocean (WCPFC). ${ }^{13}$ Peran Indonesia dapat dilihat dari keikutsertaan organisasi internasional maupun regional serta meratifikasi beberapa peraturan internasional yang berkaitan dengan konservasi sumber daya ikan di laut. Indonesia juga telah memiliki beberapa peraturan perundang-undangan yang mengatur mengenai perlindungan sumber daya ikan di laut, khususnya perlindungan ikan di laut lepas, antara lain:

1. Undang-Undang Nomor 45 Tahun 2009 tentang Perubahan atas UndangUndang Nomor 31 Tahun 2004 tentang Perikanan, Peraturan Menteri Kelautan dan Perikanan Republik Indonesia No.Per.03/Men/2009 tentang Penangkapan Ikan dan/atau Pengangkutan Ikan,

2. Peraturan Menteri Kelautan dan Perikanan Republik Indonesia Nomor 57/Permen-Kp/2014 tentang Perubahan Kedua atas Peraturan Menteri Kelautan dan Perikanan Nomor Per.30/Men/2012 tentang Usaha Perikanan Tangkap di Wilayah
Pengelolaan Perikanan Negara

Republik Indonesia,

3. Keputusan Menteri Kelautan dan Perikanan Republik Indonesia Nomor Kep.50/Men/2012 tentang Rencana Aksi Nasional Pencegahan dan Penanggulangan Illegal, Unreported, And Unregulated Fishing Tahun 20122016,

4. Peraturan Menteri Kelautan dan Perikanan Republik Indonesia Nomor Per.12/Men/2012 tentang Usaha Perikanan Tangkap di Laut Lepas.

Praktik penangkapan ikan illegal terjadi karena berbagai faktor. Menurut Nikijuluw, faktor utamanya adalah karena ikan memang selalu dibutuhkan oleh manusia. ${ }^{14}$ Ikan merupakan sumber makanan yang menjadi pilihan hampir seluruh warga dunia dan sampai saat ini permintaan atas sumber daya ikan dalam tataran global terus meningkat. Dengan demikian, tentunya ikan akan semakin berpotensi untuk sulit didapatkan, sehingga memperolehnya melalui berbagai aksi pencurian yang menjadi pilihan utama mereka dan lebih murah serta menguntungkan. Padahal, besaran sumber daya ikan tetap, bahkan cenderung berkurang karena telah diambil terlalu berlebihan. Namun, di zaman modern ini, dari beberapa literatur mengungkapkan bahwa adanya pembaharuan cara terkait praktik penangkapan ikan illegal marak terjadi, seperti illegal transhipment.

Secara de facto, permasalahan tersebut telah menjadi perhatian organisasi dunia dan regional sebagai salah satu bentuk kejahatan "Transnational Organized Crime" yang merugikan negara dan mengancam keberlangsungan sumber daya perikanan. United Nations Convention Against Transnational Organized Crime (Palermo Convention) merupakan Konvensi yang mengatur mengenai penetapan standar terhadap hukum nasional masing-masing negara pesertanya, penekanan pada perbedaan sistem hukum negara

\footnotetext{
Ibid., hlm. 86.

Muhammad Insan Tarigan, “Upaya Konservasi Indonesia atas Sumber Daya Ikan di Laut Lepas”, Jurnal Ilmu Hukum, Vol. 9, No. 4, OktoberDesember, 2015..

14 Victor P. H. Nikijuluw, 2008, Dimensi Sosial Ekonomi Perikanan Illegal: Blue Water Crime, PT Pustaka Cidesindo, Jakarta, hlm. 4.
} 
pesertanya, dan kerjasama yang dapat dibina diantara negara peserta mengenai pemberantasan kejahatan lintas batas terorganisir (Transnational Organized Crime/TOC). ${ }^{15}$ Adapun macam-macam kejahatan perikanan yang bersifat TOC, meliputi: (1) Kejahatan Genosida; (2)Perdagangan Manusia; (3) Terorisme; (4) Korupsi; (5) Pencurian ikan (illegal fishing); (6) Praktik Perbudakan; (7) Perdagangan Gelap Narkotika dan Obat Terlarang; (8) Penyelundupan Senjata; (9) Perdagangan Manusia, dan (10)Pembajakan Pesawat Udara dan Kapal Laut.

Korupsi dalam kegiatan terkait lebih mengacu kepada kegiatan terorganisir yang bersifat lintas negara, tentunya mampu memicu potensi korupsi dalam berbagai proses perizinan. Jadi, beberapa indikasi seputar tindak pidana korupsi di sektor kelautan dalam proses pengurusan Surat Ijin Usaha Perikanan (SIUP), Surat Ijin Penangkapan Ikan (SIPI), dan Surat Ijin Kapal Pengangkut Ikan (SIKPI). Selain itu, terdapat kapal ikan asing yang memperoleh SIUP atau SIPI atau SIKPI, namun tercatat bukan sebagai perusahaan penangkapan ikan atau pengangkutan ikan, tidak memiliki NPWP, ijin lokasi, dan ijin pemanfaatan pesisir. Selanjutnya, berbicara mengenai kriteria praktik illegal transhipment di laut lepas menurut United Nations Convention Against Transnational Organized Crime And The Protocols Thereto/ UNTOC sebagai Transnational Organized Crimel TOC, sebagai berikut: ${ }^{16}$

1) Kelompok penjahat terorganisasi, kelompok terstruktur yang terdiri atas 3 (tiga) atau lebih banyak orang, dengan maksud dan tujuan untuk memperoleh keuntungan yang sebesarbesarnya. Kapal pengepul yang mengumpulkan hasil tangkapan dari nelayan kecil bekerjasama, perusahaan membeli ikan langsung dari nelayan di laut, lalu ditampung dalam kapal yang dilengkapi dengan cold storage, perusahaan memberikan modal kerja. Kapal penangkap ikan dalam satu perusahaan atau manajemen memindahkan ikan di laut setelah muatan penuh ke kapal pengangkutan dengan daya muat ribuan ton dan ikan langsung di bawa ke luar negeri atau dipindahkan di pelabuhan pangkalan lalu ikan langsung diangkut oleh pengangkut ke luar negeri,

3) Kejahatan serius, melakukan kegiatan tindak pidana penangkapan ikan secara illegal,

4) Properti, penggunaan dokumen palsu atau dokumen kapal lain, tidak sahnya surat laut kapal, pelanggaran kemudahan khusus keimigrasian, tenaga kerja asing yang tidak memiliki izin kerja, mengubah kapal asing seolah-olah menjadi kapal buatan dalam negeri, dan kapal asing tidak melakukan deregistrasi (tidak lapor ulang) dikarenakan pemilik kapal tidak dapat memenuhi persyaratan untuk menunjukkan validitas serta legalitas dokumen kapal, terakhir

5) Hasil kejahatan, melanggar ketentuan peraturan penangkapan ikan.

Kesimpulannya, praktik illegal transhipment merupakan pemindahan muatan ikan yang terjadi di tengah laut lepas dari satu kapal ke kapal asing tanpa melaporkan hasil tangkapannya, sebagai bagian dari strategi usaha untuk mendapatkan keuntungan yang lebih optimal. Jadi melalui transhipment, kapal penangkap tidak perlu lagi kembali ke pangkalan setelah muatan ikan penuh. Kapal penangkap hanya menunggu kapal pengumpul (collecting ship) untuk mengambil ikan hasil tangkapan, dan pada saat itu pula kapal pengumpul menyuplai bahan bakar, bahan makanan, serta kebutuhan lainnya kepada kapal penangkap ikan tersebut. Karena letaknya strategis, Indonesia rentan terhadap berbagai bentuk kejahatan transnational.

Pengakuan masyarakat internasional atas peran aktif Indonesia dalam penanganan isuisu kejahatan transnational terorganisasi adalah dengan terpilihnya Indonesia sebagai Presiden

15 United Nations Convention Against Transnational Organized Crime and The Protocols Thereto

16 United Nations Convention Against Transnational Organized Crime and The Protocols Thereto. 
Konferensi Para Pihak (Conference of the Parties/ COP) pada United Nations Convention Against Transnational Organized Crime (UNTOC). Maka, kegiatan tersebut dapat dikategorikan sebagai salah satu bentuk kriteria Transnational Organized Crime/TOC, meliputi kejahatan yang dilakukan di satu negara, akan tetapi melibatkan kelompok kriminal terorganisasi yang berasal lebih dari satu negara, perbuatan dilakukan di suatu negara, akan tetapi substansinya disiapkan, direncanakan, dan diawasi di negara lain, kejahatan yang dilakukan di satu negara, tetapi melibatkan kelompok kriminal terorganisasi yang berasal lebih dari satu negara, dan kejahatan dilakukan di satu negara, tetapi memberi dampak di negara lain. ${ }^{17}$

2. Bentuk Penyelesaian Sengketa Praktik Illegal Transhipment di Laut Lepas Berdasarkan Hukum Laut Internasional

Berikut ini merupakan penjelasan berbagai bentuk penyelesaian sengketa yang dikenal oleh hukum internasional, yaitu:

\section{a. Perserikatan Bangsa - Bangsa (PBB)}

Salah satu alternatif penyelesaian sengketa internasional secara hukum atau judicial settlement ialah penyelesaian melalui badan peradilan internasional (world court atau internasional court). ${ }^{18}$ Mahkamah Internasional (International Court of Justice) merupakan organ yuridis dari Perserikatan Bangsa - Bangsa. Kedudukan Mahkamah berada di Istana Perdamaian (Peace Palace) di Kota Den Haag, Belanda. Mahkamah ini, sejak tahun 1946 telah menggantikan posisi dari 14 Mahkamah Permanen untuk Keadilan Internasional (Permanent Court of
International Justice) yang sudah beroperasi sejak tahun $1922 .{ }^{19}$ Fungsi utama Mahkamah Internasional adalah untuk menyelesaikan permasalahan persengketaan internasional yang subjeknya adalah negara (Pasal 34 Statuta Mahkamah Internasional). Statuta Mahkamah Internasional menjadi bagian yang tidak terpisahkan dengan Piagam PBB. Dengan demikian, ada 3 (tiga) kategori negara, antara lain:

1) Negara anggota PBB, menurut Pasal 35 ayat (1) Statuta Mahkamah Internasional dan Pasal 93 ayat (1) Piagam PBB, negara anggota PBB secara otomatis mempunyai hak untuk beracara di Mahkamah Internasional.

2) Negara anggota PBB yang menjadi anggota Statuta Mahkamah Internasional, dan Negara yang bukan anggota PBB dapat beracara di Mahkamah Internasional asalkan memenuhi persyaratan yang telah diberikan oleh Dewan Keamanan PBB atas dasar pertimbangan Majelis Umum PBB. adapun persyaratan tersebut adalah bersedia menerima ketentuan dari Statuta Mahkamah Internasional, Piagam PBB (Pasal 94), dan segala ketentuan berkenaan terhadap Mahkamah Internasional.

17 Menurut Pasal 3 UNTOC, kriteria kejahatan transnasional, yaitu:

a) It is committed in more than one State,

b) It is committed in one State but a substantial part of its preparation, planning, direction or control takes place in another State,

c) It is committed in one State but involves an organized criminal group that engages in criminal activities in more than one State, or

d) It is committed in one State but has substantial effects in another.

United Nations Office on Drugs and Crime, United Nations Convention against Transnational Organized Crime and The Protocol Thereto, New York: 2004, hlm. 6. Baca juga dalam Neil Boister, An Introduction to Transnational Criminal Law, United Kingdom: Oxford University Pers, 2012, hlm. 4 .

18 Huala Adolf, 2004, Hukum Penyelesaian Sengketa Internasional, Sinar Grafika, Jakarta, hlm.58.

19 PCIJ (Permanent Court of International of Justice) pendahulu dari ICJ, yang dibentuk berdasarkan Pasal 14 Konvenan Liga Bangsa - Bangsa pada tahun 1922. 
3) Negara bukan anggota Statuta Mahkamah Internasional, Negara yang termasuk dalam kategori ini, diharuskan untuk membuat deklarasi bahwa tunduk pada semua ketentuan Mahkamah Internasional dan Piagam PBB (Pasal 94).

Berdasarkan pada Pasal 9 Statuta Mahkamah Internasional menjelaskan, komposisi ICJ terdiri dari 15 hakim. Ke-15 (lima belas) calon hakim, dengan masa jabatan 9 (sembilan) tahun, dan direkrut dari warga negara anggota yang dinilai cakap dalam bidang hukum internasional, sedangkan untuk memilih anggota mahkamah dilakukannya pemungutan suara secara independen oleh Majelis Umum dan Dewan Keamanan. Selain 15 (lima belas) hakim tetap, Pasal 32 Statuta Mahkamah Internasional memungkinkan dibentuknya hakim ad hoc. Hakim ad hoc, terdiri dari dua hakim yang diusulkan oleh negara yang bersengketa. Kedua hakim ad hoc bersamasama dengan ke-15 (lima belas) hakim tetap memeriksa dan memutus perkara yang disidangkan baik berifat sengketa maupun nasihat.

Dalam Pasal 31 ayat (1) Statuta yang menyatakan bahwa seorang hakim Mahkamah Internasional tidak dilarang untuk memeriksa suatu kasus yang menyangkut negaranya atau kepentingan negaranya, meskipun rules of court atau bisa disebut sebagai aturan hukum acara ICJ menyatakan bahwa jika ia adalah ketua atau Presiden Mahkamah maka ia seharusnya menonaktifkan fungsinya sebagai ketua atau presiden dalam kasus tersebut. Fungsi ketua dalam hal ini digantikan oleh wakil ketua. Apabila suatu negara pada suatu sengketa tidak memiliki hakim yang berkebangsaan negaranya, ia dapat meminta agar seorang hakim ad hoc dipilih (Pasal 31 ayat (3)). Seorang hakim ad hoc diharuskan mengucap sumpah, seperti halnya seorang hakim yang dipilih suatu pihak yang hendak meminta hakim ad hoc. Peranan dan kedudukan hakim ad hoc ini sama dengan peran dan kedudukan hakim biasa namun, dalam persyaratannya hakim untuk mengambil putusan yaitu sebanyak 9 (sembilan), tidaklah termasuk suara dari hakim ad hoc.

Sedangkan Mahkamah memiliki 2 (dua) peranan, yaitu untuk menyelesaikan sengketa menurut hukum internasional atas perkara yang telah diajukan kepada mereka oleh negara dan memberikan nasihat serta pendapat hukum terhadap pertanyaan yang diberikan oleh organisasi internasional dan agen khususnya. Mengenai penanganan perkara di Mahkamah Internasional, hanya negaralah yang bisa berperkara di mahkamah. Semua anggota PBB secara ipso facto adalah anggota Mahkamah Internasional menyatakan diri tunduk kepada kewenangan mahkamah untuk memutuskan sengketa diantara mereka.

Sumber Hukum Mahkamah Internasional adalah Statuta Mahkamah Internasional dengan tegas menyatakan sumber hukum internasional yang akan mahkamah terapkan dalam menyelesaikan permasalahan sengketa yang diserahkan kepadanya, sumber hukum tersebut dinyatakan dalam Pasal 38 ayat (1) Statuta Mahkamah Internasional, yaitu: ${ }^{20}$

1) Pengadilan, yang berfungsi untuk memutuskan sesuai dengan sengketa hukum internasional seperti yang diserahkan kepadanya, berlaku:

2) Konvensi internasional, baik umum maupun khusus, aturan 
menetapkan secara tegas diakui oleh negara-negara peserta,

3) Kebiasaan internasional, sebagai bukti dari praktek umum diterima sebagai hukum,

4) Prinsip-prinsip umum hukum yang diakui oleh negara-negara beradab, dan

5) Tunduk pada ketentuan Pasal 59, keputusan hukum dan ajaran-ajaran putusan yang paling berkualifikasi tinggi dari berbagai bangsa, sebagai anak perusahaan berarti untuk penentuan aturan hukum.

Negara beserta UNCLOS 1982 dapat membawa perselisihan mereka ke Mahkamah Internasional. Namun, untuk organisasi internasional yang menjadi pihak kepada konvensi tidak dapat memilih Mahkamah Internasional, karena menurut Statutanya, mahkamah hanya memiliki yurisdiksi untuk mengadili negara. Pasal 34 ayat (1) Statuta secara kategoris menyatakan "Hanya negara yang boleh menjadi pihak dalam perkara di muka Mahkamah Internasional".

\section{b. United Nations Convention on the Law of the Sea (UNCLOS 1982)}

Konvensi PBB tentang Hukum Laut 1982 atau United Nations Convention on the Law of the Sea (UNCLOS) merupakan kodifikasi dari ketentuan internasional yang telah ada guna mengatur segala kegiatan perikanan secara komprehensif dan mewujudkan pengelolaan perikanan yang berkelanjutan, baik di dalam maupun di luar yurisdiksi negara pantai. Dalam pembukaan UNCLOS 1982 "Konvensi mengakui keinginan untuk membentuk melalui konvensi ini, mengindahkan secara layak kedaulatan semua negara, suatu tertib hukum laut dan samudera yang dapat memudahkan komunikasi internasional, memajukan penggunaan laut dan samudera secara damai, pendayagunaan sumber kekayaan alamnya secara adil dan efisien, konservasi sumber kekayaan hayatinya dan pengkajian, perlindungan dan pelestarian lingkungan laut serta konservasi kekayaan alam hayatinya". ${ }^{21}$ Sebagian besar merupakan perubahan dan kodifikasi dari ketentuan yang telah ada, akan tetapi bagian terpenting dari UNCLOS 1982 menggambarkan usaha pembaharuan yang merefleksikan adanya suatu perkembangan progresif (progressive development) dari hukum internasional.

Rezim yang melekat dari laut lepas adalah kebebasan sebagaimana tertuang pada Pasal 87 UNCLOS 1982, karena wilayah ini tidak termasuk dalam yurisdiksi suatu negara manapun. ${ }^{22}$ Dengan demikian, semua negara mempunyai kedudukan hak yang sama untuk memanfaatkan sumber daya ikan di laut lepas. Namun, UNCLOS 1982 mensyaratkan kewajiban semua negara yang memanfaatkan sumber daya ikan di laut lepas untuk saling bekerja sama dalam menciptakan kelestarian sumber daya ikan. Mengingat kebebasan penangkapan ikan dibatasi dengan kewajiban negara yang melakukan pengelolaan dan konservasi atas sumber daya hayati yang sesuai dengan ketentuan Pasal 63 ayat (2) dan Pasal 64 ayat (1) Bab VII UNCLOS 1982. ${ }^{23}$

Penyelesaian sengketa pelanggaran yang diatur dalam ketentuan internasional UNCLOS Pasal 73 ayat (1), menyatakan bahwa apabila terjadinya suatu pelanggaran di perairan yurisdiksi negara pantai, maka negara pantai tersebut berhak mengambil tindakan penegakan hukum, antara lain menaiki kapal, memeriksa kapal, dan anak buah kapal

\footnotetext{
United Nation Convention on the Law of the Sea (UNCLOS) tahun 1982

Pasal 87 United Nation Convention on the Law of the Sea (UNCLOS) tahun 1982

Pasal 63 ayat (2) dan Pasal 64 ayat (1) United Nation Convention on the Law of the Sea (UNCLOS) tahun 1982.
} 
(ABK), serta menangkap dan melakukan proses peradilan. ${ }^{24}$ Selain itu, hak mutlak pengejaran yang dimiliki oleh negara pantai terhadap pelanggaran kapal yang melalui wilayah negara pantai tersebut terutama laut territorial untuk menjaga wilayah lautnya. ${ }^{25}$ Melainkan terkait perspektif penyelesaian sengketa secara damai, UNCLOS 1982 mewajibkan suatu negara merujuk pada ketentuan Pasal 3 ayat (2) Piagam PBB. Bahwasanya, negara diberikan kebebasan untuk memilih bentuk prosedur penyelesaian sengketa dengan menggunakan sarana penyelesaian sebagaimana diatur pada Pasal 33 ayat (1) Piagam PBB. Sekalipun demikian ketentuan Pasal 33 PBB tidak meniadakan kemungkinan para pihak memilih bentuk penyelesaian sengketa secara damai lainnya, sepanjang para pihak sepakat. Prosedur ini dikatakan berhasil apabila pihak yang terlibat sengketa bersama - sama menyatakan menerima dan puas akan hasil rekomendasi atau keputusan prosedur yang dilakukan.

Jika tidak tercapai suatu kesepakatan, sebaiknya menggunakan prosedur wajib yang menghasilkan keputusan mengikat. UNCLOS menetapkan 4 (empat) aturan resolusi penyelesaian sengketa antar negara yang timbul atas penafsiran atau penerapan UNCLOS, sesuai Pasal 287 ayat (1) saat ditandatangani, diratifikasi, atau aksesi, sebuah negara bisa membuat pernyataan memilih satu atau lebih metode penyelesaian sengketa. ${ }^{26}$ Bab XV khususnya Pasal 287 UNCLOS 1982 mengatur tentang alternatif prosedur penyelesaian sengketa (dispute settlement) bagi negara yang berhubungan atau memiliki konflik di wilayah laut, menyediakan 4 (empat) forum yang dapat dipilih, yakni:

1) Mahkamah Internasional Hukum Laut (International Tribunal for the Law of the Sea (ITLOS);

2) Mahkamah Internasional (International Court of Justice ICJ);

3) Mahkamah Arbitrase (Arbitral Tribunal); dan

4) Mahkamah Arbitrase Khusus (Special Arbitral Tribunal).

ITLOS merupakan organisasi yang berkedudukan di Hamburg, Jerman dibentuk oleh mandat ketiga konferensi PBB tentang hukum laut, berfungsi sebagai penengah di antara sengketa yang lahir dari pelaksanaan ataupun penafsiran ketentuan UNCLOS 1982. Mulai berlaku sejak 16 November 1994, memiliki 21 (dua puluh satu) hakim yang berasal dari berbagai negara. Jatah 21 (dua puluh satu) hakim di ITLOS dibagi berdasarkan keterwakilan geografis. Di mana komposisinya terdiri dari 5 (lima) berasal dari Asia, 5 (lima) dari Afrika, 3 (tiga) dari Eropa Barat, 4 (empat) dari Amerika Latin dan Karibia, serta 4 (empat) dari Eropa Timur. ITLOS berfungsi untuk penanganan sengketa yang lahir dari pelaksanaan maupun penafsiran dari ketentuan UNCLOS 1982. Proses beracara ITLOS terdiri dari beberapa tahap, antara lain: ${ }^{27}$

1) Institution of proceedings and representation of parties

Dimulai dengan pengajuan aplikasi atau dengan pemberitahuan tentang special agreement. Diajukan kepada Panitera dengan menggunakan bahasa resmi dari Tribunal. Apabila proses beracara

Pasal 73 ayat (1) United Nation Convention on the Law of the Sea (UNCLOS) tahun 1982.

Pasal 111 angka 1 United Nation Convention on the Law of the Sea (UNCLOS) tahun 1982.

Pasal 287 ayat (1) UNCLOS 1982.

Rifky Setiawan, 2010, Tinjauan Yuridis Penggunaan Trade Related Measures oleh Commision for The Conservation of southern bluefin tuna (CCSBT) kepada Indonesia dalam Rangka Perdagangan Tuna Sirip Biru Selatan, Tesis, Fakultas Hukum, Universitas Indonesia, hlm. 63. 
didasarkan pada suatu agreement dan bukan konvensi, maka salinan yang disahkan (certified copy) harus disertakan pada aplikasi. Ketika proses dilakukan dengan cara aplikasi, Panitera segera mengirimkan kepada responden salinan disahkan. Dalam hal proses dilakukan dengan pemberitahuan special agreement dari satu atau lebih pihak, Panitera segera mengirimkan salinan disahkan kepada pihak lain yang bersengketa. Setelah proses dilakukan, aplikasi atau special agreement diberitahukan oleh Panitera kepada negara yang berkepentingan dan kepada semua negara pihak dalam UNCLOS 1982. Dalam organisasi internasional yang salah satu pihaknya diajukan ke Tribunal oleh pihak yang lain atau proprio motu, harus memberikan informasi sebagaimana hubungan antara organisasi dan negara anggotanya, tentang bagaimana kompetensi terhadap pertanyaan spesifik yang muncul. Proses beracara mungkin ditunda sampai informasi tersebut diterima.

2) Written proceedings

Terdiri dari komunikasi pembelaan kepada Tribunal maupun para pihak. Pembelaan berisi memorial dan countermemorial, dan apabila disetujui oleh Tribunal maka disertai juga dengan jawaban dan dokumen yang mendukung. Setelah penerimaan pembelaan, salinan pembelaan yang disahkan dan dokumen yang menyertainya dikomunikasikan oleh panitera kepada para pihak.

3) Initial deliberations

Sebelum pembukaan oral proceedings, para hakim akan bertemu dalam rangka bertukar pendapat tentang kasus tersebut.

4) Oral proceedings
Kecuali dalam kasus pelepasan kapal dan awak kapal serta provisional measures, tanggal pembukaan oral proceedings dimulai enam bulan sejak penutupan dari written kecuali ditentukan lain oleh Tribunal. Oral proceedings terdiri dari hearing oleh wakil Tribunal, pengacara, advokat, saksi dan para ahli. Hearings terbuka untuk umum kecuali ditentukan lain oleh Tribunal atau atas permintaan para pihak. Selama hearings, para pihak dapat memanggil saksi-saksi dan ahli dengan memberikan daftar kepada Tribunal. Saksisaksi dan ahli lain dapat dipanggil selama tidak ada keberatan dari pihak lain dan disetujui oleh Tribunal sesuai dengan ketentuan Pasal 78, ayat 1 Rules of Tribunal. Oral proceeding ditutup setelah seluruh presentasi tentang kasus selesai.

5) Joinder of proceedings

Tribunal bisa menjalankan proses peradilan terhadap dua atau lebih kasus yang digabungkan. Hal tersebut pernah dilakukan pada saat Southern Bluefin Tuna Cases antara Selandia Baru dan Australia melawan Jepang.

6) Default

Ketika salah satu pihak tidak hadir atau tidak dapat mempertahankan kasus, pihak lain dapat meminta tribunal untuk meneruskan proses dan membuat keputusan. Sebelum membuat keputusan Tribunal harus yakin mempunyai yurisdiksi atas kasus tersebut dan klaim tersebut didasarkan fakta dan hukum.

7) Deliberations

Setelah penutupan oral proceedings, Tribunal akan mengambil kesimpulan. Kesimpulan masih bersifat 
rahasia dan berisi rincian pasal dan perbedaan pandangan dalam pengambilan kesimpulan.

8)

Judgement

Keputusan Tribunal bersifat final dan mengikat para pihak pada saat dibacakan. Namun demikian dalam hal terjadi sengketa berkaitan dengan pemahaman keputusan maka para pihak dapat meminta interpretasi. Permintaan untuk revisi juga dapat diadakan dalam keadaan tertentu sebagaimana diatur dalam Pasal 27 ayat 1 . Satu salinan keputusan ditandatangani oleh Presiden Tribunal dan Panitera kemudian disegel dan disimpan dalam arsip Tribunal. Salinan lainnya akan dibagikan kepada para pihak, negara pihak UNCLOS, Sekretaris Jenderal PBB, dan Sekretaris Jenderal International Seabed Authority. Salinan keputusan dapat diberikan kepada publik dengan permintaan.

9) Costs

Setiap pihak beracara dengan biaya sendiri kecuali ditentukan lain oleh Tribunal. Negara juga dapat meminta pendapat kepada Tribunal berkaitan dengan interpretasi ketentuan suatu international agreement yang berkaitan dengan ketentuan UNCLOS 1982.

Salah satu faktor pendorong ITLOS dapat menetapkan UU tersebut adalah apabila situasi dalam persengketaan membutuhkan aksi untuk melindungi hak dari sang pihak pengadu untuk melindungi lingkungan laut dari kerusakan yang serius. Berhubung ITLOS di khususkan sebagai penanganan sengketa yang berhubungan terhadap kelautan, maka otomatis penyelesaiannya akan lebih cepat. c. Regional ASEAN: The Treaty of Amity and Cooperation in Southeast Asia 1976 (TAC)

Salah satu instrumen yang penting terkait upaya mewujudkan dan menciptakan stabilitas politik dan keamanan di dalam kawasan Asia Tenggara adalah the Treaty of Amity and Cooperation in Southeast Asia 1976 (TAC). Pada dasarnya prinsip yang terkandung di dalam TAC juga tercermin di dalam Piagam PBB antara lain prinsip non - interference (non - intervensi) dan penggunaan secara damai dalam menyelesaikan sengketa tanpa menggunakan kekerasan yang dapat timbul di antara negara penandatangan TAC. Mukadimah di dalam TAC menyatakan bahwa setiap pertikaian atau sengketa yang telah timbul antar negara anggota ASEAN harus dapat menghindari penggunaan cara kekerasan yang mungkin dapat membahayakan dan dapat menghambat kerjasama dalam kawasan Asia Tenggara.

TAC juga memuat tujuan dan juga prinsip yang dianut dalam kerangka persahabatan dan kerjasama antarnegara anggota ASEAN. Tujuan dari TAC sebagaimana yang tercantum dalam Bab I Pasal 1 yang menyatakan bahwa untuk dapat mempromosikan perdamaian secara terus menerus, menjalin persahabatan serta kerjasama yang baik di antara negara anggota ASEAN. TAC yang ditandatangani pada pertemuan puncak ASEAN pertama di Bali, pada tanggal 24 Februari 1976 sering disebut sebagai wujud dari nilai global yang mendasari pembentukan suatu organisasi regional. Dalam pertemuan di Bali tersebut, negara anggota ASEAN sepakat untuk saling menghormati kemerdekaan, kedaulatan, dan integritas wilayah semua bangsa, setiap negara berhak memelihara keberadaanya dari campur tangan, subversi, kekerasan dari kekuatan luar, tidak mencampuri urusan negara lain, menyelesaikan perbedaan 
pendapat dan pertikaian dengan jalan damai, menolak ancaman penggunaan kekerasan.

Rangkaian proses panjang negosiasi dapat dilihat dari penyusunan draft Piagam ASEAN diawali dengan pembentukan Eminent Persons Group on the ASEAN Charter (EPG) yang beranggotakan para tokoh terkemuka dari seluruh negara anggota ASEAN dan diketuai oleh Tun Musa Hitam (EPG - Malaysia). Pembentukan EPG ini diresmikan pada KTT ASEAN kesebelas di Kuala Lumpur, Malaysia Desember 2005 dengan ditandatanganinya Kuala Lumpur Declaration on the Establishment of the ASEAN Charter. EPG bertugas untuk memberikan masukan dan rekomendasi terhadap proses penyusunan draft Piagam ASEAN, yaitu selama masa kerjanya tahun 2006EPG telah melakukan selama 8 (delapan) kali pertemuan, antara lain melakukan dialog dengan Kepala Negara atau Pemerintahan, Sektor Bisnis, Parlemen, dan Civil Society Organizations. Melalui pertemuan tersebut telah diperolehnya masukan dan saran mengenai bagaimana Piagam ASEAN sebaiknya akan disusun (Direktorat Jenderal Kerjasama ASEAN Departemen Luar Negeri RI). EPG merekomendasikan, sebagai berikut menegaskan agar Piagam ASEAN memuat kejelasan tentang mekanisme dan struktur ASEAN yang efektif dan efisien, meningkatkan keterlibatan masyarakat di dalam berbagai kegiatan kerjasama ASEAN (people - centered organization) serta mampu memperkuat pembangunan Komunitas ASEAN.

Piagam ASEAN yang telah ditandatangani dan diratifikasi oleh seluruh negara anggota ASEAN kemudian akan mengubah ASEAN dari organisasi kawasan yang longgar menjadi sebuah organisasi yang berdasarkan aturan yang profesional atau rules - based organisation. Keberadaan Piagam ASEAN akan memberikan suatu kerangka hukum dan institusional bagi ASEAN untuk dapat berkembang ke arah sebuah komunitas bersama yang mengedepankan antara lain yaitu perdamaian, keamanan, stabilitas, pertumbuhan ekonomi berlanjut, kesejahteraan, dan kemajuan sosial. Berbicara mengenai konteks regional ASEAN, oleh karena $^{28}$ itu mekanisme penyelesainnya lebih memilih secara damai atau diplomatik tanpa menggunakan suatu cara kekerasan atau dengan menggunakan perang, tertuang pada ketentuan Pasal 22 sampai dengan Pasal 28 dalam Piagam ASEAN yang mengatur mengenai mekanisme penyelesaian sengketa di ASEAN, ${ }^{29}$ yang merupakan repetisi dari Pasal 13 sampai dengan Pasal 17 TAC dan merupakan imitasi dari Pasal 33 Piagam $\mathrm{PBB}$, beberapa diantaranya:

1) Pasal 22 tentang Prinsip Umum, berbunyi "Negara Anggota wajib berupaya menyelesaikan secara damai semua sengketa dengan cara yang tepat waktu melalui dialog, konsultasi, dan negosiasi. ASEAN wajib memelihara dan membentuk mekanisme penyelesaian sengketa dalam segala bidang kerjasama ASEAN".

2) Pasal 23 tentang Jasa Baik, Konsiliasi, dan Mediasi, berbunyi "Negara - Negara Anggota yang merupakan para pihak dalam suatu sengketa dapat sewaktu - waktu sepakat untuk menggunakan jasa baik, konsiliasi atau mediasi dalam rangka menyelesaikan sengketa 
dengan batas waktu yang telah disepakati. Para pihak dalam sengketa dapat meminta Ketua ASEAN atau Sekretaris Jenderal ASEAN, bertindak dalam kapasitas ex - officio, menyediakan jasa - jasa baik, konsiliasi, atau mediasi".

3) Pasal 26 tentang Sengketa Yang Tidak Terselesaikan, berbunyi "Apabila suatu sengketa tetap tidak terselesaikan, setelah penerapan ketentuan terdahulu, maka sengketa wajib dirujuk ke Konferensi Tingkat Tinggi ASEAN, untuk keputusannya".

Selain itu, Piagam ASEAN tidak hanya membatasi jenis persengketaan tertentu saja yang bisa diselesaikan melalui mekanisme yang ditentukan oleh piagam. Pada era globalisasi ini, dimana sengketa antar negara merupakan sengketa perdagangan dan ekonomi, mekanisme penyelesaian sengketa PBB bukanlah merupakan suatu jawaban yang baik. Sebab, suatu sengketa politik dan diplomatik tepatnya geopolitik, tidak mungkin terlepas dari muatan ekonomi dan geo-ekonomi. Terlepas dari persoalan tersebut, yang pasti adalah dalam bentuk apapun obyek sengketa yang terjadi di kalangan anggota ASEAN, Piagam ASEAN sebisa mungkin menekankan untuk menggunakan cara diplomasi dalam penyelesaiannya, seperti negosiasi, konsiliasi, mediasi, jasa baik, dan lain sebagainya yang telah disepakati oleh para pihak. Prinsip ini dipilih semata - mata untuk tetap menjaga stabilitas dan keharmonisan dalam suatu hubungan bilateral antar anggota ASEAN itu sendiri.

Cara penyelesaian sengketa secara damai dapat dilakukan apabila para pihak telah menyepakati untuk menemukan suatu solusi yang bersahabat. J.G.
Starke mengklasifikasikan suatu metode penyelesaian sengketa internasional secara damai, antara lain arbitrase, penyelesaian yudisial (judicial settlement), negosiasi, jasa - jasa baik (good offices), mediasi, konsiliasi, pencarian fakta (inquiry), dan penyelesaian di bawah naungan organisasi PBB. Arbitrase merupakan cara alternatif itikad baik penyelesaian sengketa hukum internasional yang diajukan oleh arbitrator, dimana ia dipilih secara bebas tanpa harus memperhatikan ketentuan hukum yang ketat. Hakikatnya ialah prosedur penyelesaian sengketa hanya dapat dilakukan melalui persetujuan negara bersengketa. Penyerahan sengketa kepada arbitrase dengan menempatkannya di dalam perjanjian internasional antar negara bersangkutan. Perjanjian internasional itu mengatur pokok sengketa yang dimintakan arbitrasi, penunjukkan tribunal arbitrasi, batas wewenang arbitrasi, prosedur arbitrasi, dan ketentuan yang dijadikan dasar pembuatan keputusan arbitrasi.

Penyelesaian Yudisial (Judicial Settlement) juga dapat disamakan dengan suatu peradilan internasional. Peradilan Internasional penyelesaian sengketa dengan menerapkan ketentuan hukum yang dibentuk secara teratur. Pengadilan dapat dibagi ke dalam dua kategori yaitu pengadilan permanen dan pengadilan ad hoc atau pengadilan khusus. Pengadilan internasional permanen, contohnya adalah Mahkamah Internasional (ICJ). Peradilan internasional berbeda dengan arbitrasi internasional dalam beberapa hal, antara lain Mahkamah secara permanen merupakan sebuah pengadilan, yang diatur dengan statuta dan serangkaian ketentuan prosedurnya yang mengikat terhadap semua pihak yang berhubungan dengan Mahkamah. Mahkamah memiliki panitera atau register tetap, yang telah menjalankan semua fungsi diperlukan dalam menerima dokumen untuk arsip, dilakukan 
suatu pencatatan dan pengesahan, pelayanan umum Mahkamah, dan bertindak sebagai saluran komunikasi tetap dengan pemerintah. Proses peradilan dilakukan secara terbuka, sementara pembelaan dan catatan dengan pendapat serta keputusannya dipublikasikan. Pada prinsipnya, Mahkamah dapat dimasuki oleh semua negara untuk proses penyelesaian yudisial segala kasus yang dapat diserahkan oleh negara - negara tersebut kepadanya dan semua masalah diatur pada traktat dan konvensi. Pasal 38 Statuta Mahkamah secara khusus menetapkan bentuk hukum yang berbeda - beda di mana harus diberlakukannya mahkamah di dalam sebuah perkara yang telah diajukan kehadapannya, tanpa menyampingkan mahkamah memutuskan suatu perkara ex aequo et bono apabila para pihak setuju terhadap cara tersebut.

Negosiasi sering dikaitkan dengan jasa - jasa baik (good offices) atau mediasi. Sebelum dilaksanakannya negosiasi, ada dua proses yang telah dilakukan terlebih dahulu, yaitu konsultasi dan komunikasi. Tanpa kedua media tersebut, seringkali dalam beberapa hal negosiasi tidak dapat berjalan. Keuntungan yang diperoleh ketika negara bersengketa, antara lain para pihak memiliki kebebasan untuk menentukan penyelesaian sesuai dengan kesepakatan diantara mereka, para pihak mengawasi dan memantau secara langsung prosedur penyelesaiannya, dapat menghindari perhatian publik dan tekanan politik dalam negeri, para pihak mencari penyelesaian bersifat win - win solution, sehingga dapat diterima dan memuaskan kedua belah pihak. Sedangkan, kelemahan utamanya ialah Pertama, manakala kedudukan dari para pihak tidak seimbang, salah satu pihak kuat sedang pihak yang lain lemah. Dalam keadaan ini, pihak yang kuat berada dalam posisi untuk menekan pihak lainnya. Hal ini, sering kali terjadi manakala dua pihak bernegosiasi untuk menyelesaikan sengketa di antara mereka. Kedua, bahwa proses berlangsungnya suatu negosiasi lambat dan memakan waktu lama. Hal ini terutama dikarenakan suatu permasalahan antarnegara yang timbul. Selain itu juga, jarang sekali adanya persyaratan penetapan batas waktu bagi para pihak untuk menyelesaikan sengketanya melalui negosiasi. Ketiga, manakala salah satu pihak terlalu keras dengan pendiriannya, keadaan ini dapat mengakibatkan proses negosiasi menjadi tidak produktif.

Jasa - jasa baik (good offices) dan mediasi merupakan cara penyelesaian sengketa internasional di mana negara ketiga yang bersahabat dengan para pihak yang bersengketa membantu penyelesaian secara damai. Pihak yang menawarkan jasa - jasa baik atau mediator bisa berupa individu atau juga organisasi internasional. Perbedaan antara jasa - jasa baik dengan mediasi adalah persoalan tingkat. Apabila jasa - jasa baik, pihak ketiga menawarkan jasa untuk mempertemukan pihak yang bersengketa. Selain itu, pihak tersebut mengusulkan (dalam bentuk syarat umum). Tetapi, ia sendiri secara nyata tidak ikut serta dalam pertemuan. Demikian pula, ia tidak melakukan suatu penyelidikan secara saksama atas beberapa aspek dari persengketaan. Sebaliknya mediasi memiliki suatu peran yang lebih aktif untuk mencari solusi yang tepat untuk melancarkan terjadinya kesepakatan antara pihak yang bertikai dan untuk menciptakan adanya suatu kontak atau hubungan langsung di antara para pihak. Tujuannya adalah untuk menciptakan adanya suatu kontak atau hubungan langsung di antara para pihak. Mediator bisa negara, individu, ataupun organisasi internasional. Sedangkan, jika dilihat dari segi negatif mediasi adalah mediator yang dapat saja dalam melaksanakan fungsinya lebih memperhatikan pihak lainnya. Proses penyelesaian sengketa melalui mediasi 
ini hampir mirip dengan konsilisasi. Perbedaannya, pada mediasi umumnya mediator memberikan usulan penyelesaian secara informal dan usulan tersebut didasarkan pada laporan yang diberikan oleh para pihak, tidak dari hasil penyelidikan sendiri. Perlu ditekankan disini, bahwa saran atau usulan penyelesaian yang diberikan tidaklah mengikat sifatnya, nya hanya berupa rekomendatif atau usulan saja.

Konsiliasi menurut the Institute of International Law melalui the Regulations on the Procedure of International Conciliation yang telah diadopsinya pada tahun 1961 dalam Pasal 1 dinyatakan, sebagai suatu metode dari penyelesaian sengketa bersifat internasional di dalam suatu komisi yang dibentuk oleh pihak-pihak, baik sifatnya permanen atau ad hoc (sementara) berkaitan dengan proses penyelesaian sengketa. Proses seperti ini berupaya mendamaikan pandangan para pihak yang bersengketa meskipun berbagai upaya penyelesaian yang dibuat oleh konsiliator sifatnya tidak mempunyai kekuatan hukum. The Hague Convention for the Pacific Settlement of International Dispute of 1899 and 1907 memuat suatu mekanisme dan aturan pembentukan komisi konsiliasi. Badan seperti ini hanya bisa dibentuk dengan persetujuan bersama para pihak. Pada umumnya, badan ini diberi mandat untuk mencari dan melaporkan fakta yang ada di sekitar pokok sengketa.

Ketika terjadi pertikaian mengenai fakta dari suatu persoalan, metode inquiry dapat dipandang paling tepat. Sebab metode ini digunakan untuk mencapai penyelesaian sebuah sengketa dengan cara mendirikan sebuah komisi atau badan yang bersifat internasional untuk mencari dan mendengarkan semua bukti yang relevan. Tujuan dari pencarian fakta untuk mencari fakta yang sebenarnya adalah membentuk suatu dasar bagi penyelesaian sengketa di antara dua negara, yaitu mengawasi pelaksanaan dari suatu perjanjian internasional, dan memberikan informasi guna membuat suatu putusan di tingkat internasional. Menurut penulis, Regional ASEAN hanya memberikan fasilitas mediasi, bukan untuk mengadili bahkan memutuskan suatu perkara penyelesaian sengketa.

\section{Penutup}

Perairan Negara Indonesia mempunyai potensi kekayaan sumber daya laut yang begitu besar memberikan sejumlah peluang dan tantangan. Di satu sisi, perairan Indonesia menyajikan berbagai sumber daya guna kesejahteraan atau kemakmuran bagi bangsa Indonesia baik memenuhi kebutuhan rakyatnya maupun keperluan ekspor suatu negara. Namun disisi lain, Indonesia menghadapi suatu tantangan untuk menjaganya dari potensi ancaman yang terjadi. Salah satu tantangan terbesar bagi Indonesia adalah menjaga teritorial perairannya dari aktivitas penangkapan ikan secara illegal. Maraknya aktivitas ini mengancam kelangsungan hidup industri perikanan Indonesia. Dalam hal kegiatan perikanan, cara penangkapan ikan dan alat yang dipergunakan berkembang sangat cepat untuk memperoleh ikan dalam waktu relatif singkat dan jumlah yang cukup besar, yaitu melalui praktik illegal transhipment diartikan sebagai pemindahan muatan ikan yang terjadi di tengah laut lepas dari satu kapal ke kapal asing tanpa melaporkan hasil tangkapannya tersebut. Modusnya, kapal tersebut menjual ikannya di laut lepas tanpa melaporkan hasil tangkapannya, baru pada tangkapan terakhir atau saat periode perizinan hampir berakhir, mereka biasanya melaporkan kepada pejabat yang berwenang di Indonesia. Pada saat di kapal pun, pencatatan jumlah ikan yang ditangkap tidak dihitung kembali secara cermat. Jadi melalui transhipment, kapal penangkap tidak perlu lagi kembali ke pangkalan setelah muatan ikan penuh. Kapal penangkap hanya menunggu kapal pengumpul (collecting ship) untuk mengambil ikan hasil tangkapan, dan pada saat itu pula kapal pengumpul menyuplai bahan bakar, 
bahan makanan, serta kebutuhan lainnya kepada kapal penangkap ikan tersebut.

Modus-modus tersebut dapat dikategorikan sebagai salah satu bentuk kriteria Transnational Organized Crime/TOC, meliputi kejahatan yang dilakukan di satu negara, akan tetapi melibatkan kelompok kriminal terorganisasi yang berasal lebih dari satu negara, seperti kasus illegal transhipment di Benoa, Bali. Di mana, jaringan illegal fishing di tengah laut melakukan kegiatan transhipment (alih muatan) kepada kapal induk dari Taiwan.

Kenyataannya, praktik illegal transhipment dilakukan oleh pihak tertentu yang tidak bertanggungjawab, diluar sepengetahuan ataupun izin dari negara yang asli. Sebelum kapal berlabuh untuk menangkap ikan, pelabuhan asal akan menetapkan jumlah tangkapan yang boleh ditangkap (apabila statusnya adalah Kapal Asing) dan menetapkan kewajiban pelaporan hasil tangkapan ikan di Pelabuhan destinasi selanjutnya. Menurut RFMOs, otoritas yang berwenang berhak memberikan izin untuk melakukan bongkar muat tangkapan ikan di laut lepas apabila terdapat beberapa kondisi yang memang berbahaya bagi kapal apabila tidak dilakukannya bongkar muat.

Menurut UNCLOS Part. XV. High Seas, Article 94 Duties of The Flag State, setiap negara wajib memberlakukan yurisdiksinya serta pengawasan terhadap hal administratif teknikal, dan sosial terhadap setiap kapal yang mengibarkan benderanya di Laut Lepas. Menurut UNCLOS pula, suatu Negara Pantai harus menghormati berbagai kebebasan yang diatur dalam rezim Laut Lepas, kecuali apabila melanggar peraturan hukum internasional. Mengenai transhipment sendiri apabila suatu kapal terbukti melakukan illegal transhipment di Laut Lepas tanpa seizin otoritas yang berwenang, maka ini sudah menjadi kewajiban Negara Pantai untuk melakukan pengawasan dan memberlakukan yurisdiksinya, karena dapat dilihat melalui berbagai teknologi pemantauan lokal kapal seperti yang telah dianjurkan oleh RFMOs dan telah dilakukan oleh Taiwan, Korea, Jepang, dan Ghana ketika mendeteksi praktik illegal transhipment di Laut Lepas.

Meskipun terdapat banyak bentuk penyelesaian sengketa di UNCLOS, namun untuk transhipment di Laut Lepas sendiri tidak dapat langsung dijustifikasi dapat diselesaikan mengenai berbagai bentuk penyelesaian sengketa yang ada. Pertama, mengingat illegal transhipment bukanlah termasuk ke dalam sengketa, namun sebagai pelanggaran dalam praktik penangkapan ikan. Kedua, Negara Bendera Kapal memiliki yurisdiksi atas kapal di Laut Lepas, termasuk pula menginvestigasi praktik illegal transhipment yang mungkin dilakukan. Oleh sebab itu, transhipment hanya dapat ditegakkan melalui Negara Bendera Kapal atas dasar UNCLOS 1982 dan RFMOs. Resolusi PBB dan Regional ASEAN tidak dapat menjadi forum dalam melakukan penegakan hukum terhadap transhipment di Laut Lepas.

\section{DAFTAR PUSTAKA}

\section{A. Buku}

Adolf, Huala, 2004, Hukum Penyelesaian Sengketa Internasional, Sinar Grafika, Jakarta.

Hidayati, Ratnaningsih, 2015, ASEAN Satu Komunitas Satu Identitas, Deepublish, Yogyakarta.

Nikijuluw, Victor P. H., 2008, Dimensi Sosial Ekonomi Perikanan Illegal: Blue Water Crime, PT Pustaka Cidesindo, Jakarta.
Siombo, Marhaeni Ria, 2010, Hukum Perikanan Nasional dan Internasional, PT Gramedia, Jakarta.

Starke, J.G., 1988, An Introduction to International law, Butterworths, London.

Thontowi, Jawahir dan Pranoto Iskandar, 2006, Hukum Internasional Kontemporer, PT. Refika Aditama, Bandung. 


\section{B. Artikel Jurnal}

Salsabila, Aldhanalia Pramesti, "Pengoptimalan Satgas 115 dengan Model Koordinasi Satgas Pusat dan Daerah Sebagai Bentuk Pencegahan Illegal Transhipment di Indonesia", Lex Scientia Law Review, Vol. 2, No. 1, Mei, 2018.

Tarigan, Muhammad Insan, "Upaya Konservasi Indonesia atas Sumber Daya Ikan di Laut Lepas", Jurnal Ilmu Hukum, Vol. 9, No. 4, Oktober-Desember, 2015

Tsamenyi, Martin, et.al, "The European Council Regulation on Illegal, Unreported and Unregulated Fishing: An International Fisheries Law Perspective", The International Journal of Marine and Coastal Law, Vol. 25, 2010.

\section{Hasil Penelitian/Tugas Akhir}

Setiawan, Rifky, 2010, Tinjauan Yuridis Penggunaan Trade Related Measures oleh Commision for
The Conservation of southern bluefin tuna (CCSBT) kepada Indonesia dalam Rangka Perdagangan Tuna Sirip Biru Selatan, Tesis, Fakultas Hukum, Universitas Indonesia.

\section{Internet}

Fitrahudin, Ahmad Ziaul, "Menteri Susi Selidiki Transhipment Illegal Fishing di Wilayah ini”, https://m.detik.com/news/berita/d-3286337/ menteri-susi-selidiki-transhipment-illegalfishing-di-wilayah-ini, diakses 22 Desember 2018.

\section{E. Dokumen Lain}

Piagam Association of Southeast Asian Nations.

Statuta Mahkamah Internasional.

United Nation Convention on the Law of the Sea (UNCLOS) tahun 1982.

United Nations Convention Against Transnational Organized Crime And The Protocols Thereto. 